\title{
In Search of Moderation of Islam Againts Extremism: A Promoting "Islam Pribumi” By Gus Dur
}

\author{
Muzayyin \\ Institut Agama Islam Nahdlatul Ulama Kebumen, Indonesia \\ Muhamadmuzayyino64@gmail.com \\ Nadia Raifah Nawa Kartika \\ Institut Agama Islam Nahdlatul Ulama Kebumen, Indonesia \\ nadiaranaka22@gmail.com
}

\begin{abstract}
Habib
Universitas Islam Negeri Sunan Kalijaga Yogyakarta, Indonesia

habib.kamil72@gmail.com
\end{abstract}

\begin{abstract}
Abstrak
Ekspresi keagamaan di Indonesia menghadapi tantangan luar biasa dengan munculnya gerakan fundamentalis yang berafiliasi dengan gerakan transnasionalis Islam dari Timur Tengah, yang secara kaku meneguhkan ideologi "penyucian" atau yang disebut Islam Kaffah. Terkait dengan hal ini, Gus Dur menghadirkan pola keagamaan alternatif lain dengan mengusung gagasan Islam Pribumi atau "Islam Pribumi" yang berarti merespon dan menentang gerakan fundamentalis-skripturalis. Islam Pribumi dimaksudkan untuk memberikan peluang keragaman tafsir dalam mengamalkan kehidupan beragama (Islam) di setiap daerah yang berbeda. Dengan demikian, Islam tidak lagi dipandang sebagai satu kesatuan, melainkan majemuk. Sehingga tidak ada lagi anggapan bahwa Islam di Timur Tengah adalah representasi terbaik dari Islam. Oleh karena itu, tulisan ini mencoba menelaah pemikiran Gus Dur tentang Islam Pribumi yang sesungguhnya merupakan budaya Islam yang inklusif, toleran dan damai, yang mencerminkan Islam sebagai rahmatal lil 'alamin. Selain itu, untuk menawarkan model Moderasi Islam yang memberikan solusi dalam mewujudkan perdamaian global terhadap konflik antar agama dan politik yang paling akhir terjadi di negara berpenduduk mayoritas Muslim seperti Suriah, Afghanistan, Irak, dan Yaman.
\end{abstract}

Katakunci: Ekstrimism, Gus Dur, moderasi, Islam pribumi, purifikasi 


\begin{abstract}
Indonesian religious expressions are facing an extraordinary challenge with the emergence of fundamentalist movements affiliated with number of Islamic transnationalist from Middle East, which is rigidly establishing the ideology of "purification" or as so called Islam Kaffah even if to be forced to the all nation. In this Case, Gus Dur presented another alternative religious pattern by promoting the idea of Islam Pribumi or "Islam Pribumi" which mean to respon and againts this scripturalist-fundamentalist movement. Islam Pribumi is intended to provide opportunities for the diversity of interpretations in term of practicing religious life (Islam) in each different region. Thus, Islam is no longer seen as a single, but rather compound. So there is no longer an assumption that Islam in the Middle East is the best representative of Islam. Therefore, this paper attempts to examine Gus Dur's thoughts on Islam Pribumi which is definitly inclusive, tolerant and peaceful Islamic culture, relflecting Islam as rahmatal lil alamin. It is also to offer a model of Islamic Moderation provided a solution in realizing global peace against conflicts between religions and politics that has occurred most recently in a Muslim-majority country like Syria, Afghanistan, Iraq, and Yemen.
\end{abstract}

Keywords: Extremism, Gus Dur, Islam pribumi, moderation, purification

\title{
Introduction
}

The emergence of several radical Islamic organizations, scripturalfundamentalist which has been quite prominent in recent years, has become a challenge and even a threat to the existence and patterns of expression of diversity of (Islam) that becomes typical of the Nusantara. This group became prominent not because of its population but mainly because of religious understanding which tends to be literal and its actions tends to be radical (Azra, 2004: 33-34). It is said to be a challenge because they are trying to carry out the "Arabization" project in every Islamic community throughout the world by means of purification or authentication as a perfect living system. It is considered as a threat because they tend to approach in a hard and forceful ways to achieve their goals, rather than a peaceful and persuasive approach.

The mainstream religious understanding believed by the majority of the population is considered as untrue understanding, because it is different from the ideal Islam. Islam is exemplified by the Salaf al-shalih, the uniqueness of the expression of Islamic society in Indonesia is seen as "modern ignorance" which is far from true, authentic, and original Islam. Islamic authenticity disappears when it is interfered by other elements. Islam in Nusantara is considered to lose its authenticity value since it accommodates and acculturates with the local culture and socio-political system (Van Leur, 1955: 169). The inclusion of the various local cultures is considered as providing bid'ah or khurafat. Therefore, Indonesian Islam must be re-Islamised with the banner of puritanism, purification (Rahmat, 2003: 11). 
The presence of these mass organizations according to Rahmat (2003: xviii) has presented a real alternative to the other colors of religion with the slogan "Islam Kaffah". The religion they call "authentic", Islamic and kaffah which should be applied throughout the world because such Islam is universal (saheeh li kulli zaman wa makan, suitable for all places and all eras) (Rahmat, 2003: xviii). But, behind the claims of its authenticity and universality, there is another fact which is enough to make people ask a question; Is what it called authentic should tend to be Arabic? This is where the importance of examining Gus Dur's thoughts about Islam Pribumi is intended to provide opportunities for the diversity of interpretations in the practice of religious life (Islam) in each different region. Thus, Islam is no longer seen as a single, but rather complex. So there is no longer an assumption that Islam in the Middle East is the true Islam. "Arabization" or the process of identifying ourselves with Middle Eastern culture is uprooting us from our own cultural roots.

According to the background of the study above, there are two statements of the problem; 1). How the concept of Islam Pribumi model initiated by Gus Dur is?; 2). How Islam Pribumi reasons based on Gus Dur's thought is?. These statements of the problem are intended as an effort to present the face of Islam that emphasizes moderation in expressing religious knowledge between religious communities. On the other side, the format of Gus Dur's Islam Pribumi is a solution to reduce the tension of Islamic conflicts expressed by Transnational Islam in the Middle East which is scriptualistfundamentalist.

\section{Islam Pribumi: The Model of Islam Nusantara by Gus Dur}

Abdurrahman Wahid, who is commonly called Gus Dur, was born from a pesantren from the couple of Wahid Hasyim and Nyai Solechah. His parents were also a charismatic ulama who found the Islamic Boarding School and founder of NU. Wahid Hasyim is the son of the founder of NU, K.H. Hasyim Asy'ari, while Solechah is the daughter of KH. Bisri Syamsuri, one of the NU's figures (Barton, 2002: 38). Like most kyiai children, Wahid also received pesantren education, including; Pesantren Al-Munawwir, Krapyak, Yogyakarta 1957. Pesantren Tegalrejo, Magelang 1959. Pesantren Denanyar, Jombang 1957. Pesantren Tambakberas, Jombang 1963. Among pesantren, he was considered a brilliant student. In his studies, Gus Dur depends a lot on the power of memory, because he does have a strong memorizing power, so that his teacher hardly gives a challenge to Gus Dur, however, he is known as a lazy and lacking discipline in his formal studies. Unlike other santri, Gus Dur was the only santri 
who was able to master several foreign languages such as Arabic, English and Dutch. His mastery in several languages is very influential on the reading material he reads (Barton, 2002: 56). His interest in science is extraordinary, various books have been read, not only from the works of traditionalist clerics that are referred to as Islamic boarding schools, but also Western works especially about the social theories of Western liberal thinkers, such as Das Kapital, Karl Mark, and Infantile Communism, by Lenin (Barton, 2002: 59).

\section{Pribumisasi Islam: The Model of Islam Nusantara by Gus Dur}

In 1963 Gus Dur left for Cairo to continue his studies with the help of a Ministry of Religion scholarship with Zakiyah Darajat, Muhibbubin Wali and others. He entered the Higher Institute for Islamic and Arabic Law Al-Azhar University, but then moved to the land of 1001 nights (Iraq) and took Arabic literature at the Faculty of Letters of Baghdad University in Baghdad until graduating from the LAS (Language Arabic Science) in 1970 (Suprapto, 2009: 110). He spent much of his time reading in the library of the American University, the Cairo University library, and the French Library. There, he explored various streams in Islamic thought, even struggling in various socioreligious organizations (Barton, 2002: 84). In the 1960s, Gus Dur was learned seriously both of "Arab Nationalisms" in Egypt and "Arab Socialism" in Baghdad. Upon returning from the Middle East, around the 1970s, Gus Dur saw that the religious development in Indonesia was different from the Middle East (Wahid, 2011: 66). In Indonesia, Gus Dur saw Islam as a way of life, in which all people in one another learned and adopted various non-religious ideologies, as well as various views from other religions (Wahid, 2011: 67-68).

His religious experience and intellectual wanderings greatly influenced Gus Dur's way of thinking in understanding Islam. He then formulated a very extraordinary Islamic concept, known as, my Islam, your Islam, and our Islam (Anwar, 2011: xiv). My Islam, is Islam that I (Gus Dur) experienced, which will never be experienced by anyone else. Because of this, Gus Dur insisted that he must be proud of his religious experience, but should not force it on others. Your Islam is Islam that was born from the beliefs of other people (you), and not from Gus Dur's experience, and I (Gus Dur) can't even experience. Gus Dur gave an example of Muslims who visited the commemoration of Sunan Bonang's haul in Tuban. They came to the haul without considering whether Sunan Bonang really lived or not. But with certain beliefs, they still attend. While our Islam is Islam that think about the progress of Islam in the future. It was formulated because its initiators were concerned about the future of 
religion, so that the concern referred to the common interests of the Muslims. Because it has a general character and concerns to the fate of the Muslims as a whole. Our Islam includes my Islam and your Islam (Wahid, 2011: 67).

Gus Dur brought up the idea of Islam Pribumi in the late 1980s, in response to "authentic Islam" or "pure Islam" which wanted to carry out an Arabization project in every Islamic community throughout the world. Islam Pribumi actually provides a variety of interpretations in the practice of religious life (Islam) in each different region. Thus, Islam is no longer seen as a single, but diverse. There is no longer the assumption of Islam in the Middle East as a purest and truest Islam, because Islam as a religion sustains a continuing historicity (Zada, 2003: 9-10). However, as an idea, of course there are some groups that are pros and cons. The idea of Islam Pribumi on the one hand became an interesting discourse and became a hot topic especially for young and old intellectuals, on the other hand for those who were mainly on the opposite especially in Kyai's circle, they rejected this idea. On March 8-9 1989 approximately 200 kyai gathered at the Darut Tauhid Arjawinangun Islamic Boarding School in Cirebon to "arbitrate" Gus Dur. This moment then caused the emergence of several opposing camps in addressing the discourse rolled out by Gus Dur in connection with his Islam Pribumi ideas. However, as Gus Dur himself admitted, he was not the first to start. He is the next generation of strategic steps ever taken by Walisongo (Baso, 2006:284).

By using pribumisasi concept, according to Gus Dur, Wali Songo succeeded in Islamizing Javanese land, without having to confront and experience tension with the local culture. Walisongo has succeeded in incorporating local values in Islam which is typically Indonesian. Walisongo's creativity brought a new idea of Indonesian Islamic comprehension that did not literally imitate Islam in Arabic. There is no reason for Arabization inherent in the spread of early Islam in Nusantara. Walisongo actually accommodates Islam as a religion principle that experiences historicity with culture. For example, what Sunan Bonang did by changing Javanese Gamelan which at that time was thick with Hindu aesthetics, became the nuances of dzikir which encouraged a love of transcendental life. The song "Tombo Ati" is one of Sunan Bonang's creation. In the wayang performance, Sunan Bonang changes the play and includes typical interpretations of Islam. Likewise, what was done by Sunan Kalijaga who chose art and culture as a means to do da'wah. He is very tolerant of culture. He argues that society will stay away if their reliance is attacked through purification. They must be approached step by step: following while influencing. Sunan Kalijaga believes that if Islam is understood, the old habits 
will naturally disappear. He uses carving, wayang, gamelan, and suluk music as a tool of doing da'wah. He is also the initiator for the creator of taqwa cloth, sekaten celebration, Grebeg Maulud, etc. (Rahmat, 2003:10).

That is what Walisongo inherited from Islamic da'wah to Nusantara, by not purifying or authenticating Islamic principles totally, but by making adaptations to the socio-cultural conditions of the local community. So they do not take action against the new teachings brought by Walisongo. Other important values of Walisongo's inheritance that is very clear, for example, in terms of how they dressed up, they still wore traditional clothes, which was considered to fulfil qualification for covering the aurat by some local ulama. Even the female ulama and the wives of some kyai wore traditional clothing, as other local people did. Therefore, this strategy was carried out in addition to familiarizing Islam with the local environment, and also provided opportunities for the traditional clothing industry to continue to develop, so that they were not economically disrupted by the presence of Islam. What we can see now, Islam is very thick with local environment, so that each regional Islam can display their Islamic spirit specifically based on their traditions (Fitriah, 2015: 45).

\section{Islamic Universalism}

Gus Dur offers a theoretical concept of Islamic universality. He acknowledged that Islam is a universal religion in which Islamic values are the objective of Islamic law. Islamic universalism exposes itself in various important manifestations, the best is in its teachings. The squences of teachings covering various fields, such as religious law (fiqh), faith (monotheism), ethics (morality), and attitudes to life, which according to Gus Dur show enormous concern for humans (Wahid, 2007: 3). Its principles such as equality before the law and constitution, protection of citizens from tyranny and abuse, the right defense of the weak people and those who suffering from deficiencies, as well as the authority limit of the stakeholders, shows the concern of Islam towards humans. In this case, it is clear that the Islamic universalism initiated by Gus Dur is to place humans as subjects to be defended. "God does not need to be defended" is one of the titles of his book which emphasizes that those who need to be defended are humans especially when they get threats or experience oppression in all aspects of life, whether political, economic, social, cultural and religious. The consequence of the defence according to Gus Dur is criticism and sometimes forced to declaim, if it is over the limit of tolerance (Wahid, 2011: v-vi). Concrete form of Islamic 
universalism in its defence of humans is the existence of five guarantees that are fundamentally existed in humans, for instance; 1 ). the guarantee of human safety from physically actions outside the provisions of the law; 2). The assurance of individual religious beliefs without coercion to convert; 3 ). The assurance of family and heredity; 4). the assurance of property and personal asset from interference or from eviction outside the law procedure; 5).

The assurance of ownership rights and the profession. Those five guarantees of Islamic teachings according to Gus Dur require consequences. The guarantee of "physical safety" requires the existence of a government based on law, with fair treatment to all citizens without exception, in accordance with their respective rights. The guarantee of "religious belief" underpins the relationship between citizens on the basis of mutual respect, thus it encourages the growth of tolerance, great mutual understanding, and tolerance. The guarantee of "family assurance and heredity" exposes a strong moral figure in the family, because the family is a vital organ of social life. The guarantee of "property assurance" is a means of developing the individuals rights properly and proportionally, especially in relation to society in general.

The guarantee of "profession rights" creates freedom for individuals to have and to choose a profession with its own risk and responsibility (Wahid, 1988). According to Gus Dur, if those five elements appear as a view of life and are coincident, then it is not impossible that the state can be managed by a government that is based on law, the existence of a degree equality and tolerance attitude for different views (Wahid, 1988).

\section{Islamic Cosmopolitanism}

Gus Dur saw that the principles and manifestations of Islamic universalism were still theoretical, and did not work when not supported or balanced with cosmopolitanism (openness). Cosmopolitanism in question is an attitude of openness with other civilizations and is willing to communicate dialogically and critically with one another based on the values and principles of openness. According to him, this attitude of openness has been exemplified by our predecessors, even from the prophet Muhammad SAW when organizing society in Medina and Muslim experts who often dialogued with the principle of openness with outside civilizations such as Greek civilization. At that time, the civilization of Islam absorbed each other with other civilizations. This openness attitude is what ultimately makes Islamic civilization rich with scientific disciplines. In Islamic cosmopolitanism, ethnic boundaries are lost, 
cultural plurality is increasingly strengthened and political reality is more heterogeneous. Moreover, Islamic cosmopolitanism according to Gus Dur appeared in the form of eclectic religious life. Eclecticism arises from Islam's open dialogue with other civilizations. According to Gus Dur, Islamic cosmopolitanism will be achieved at the optimal point when a balance between the normative tendencies of Muslims and freedom of thought are attained.

Religious norms are still used as a fundamental in thinking, but not to fetter freedom of thought. Conversely, never let freedom of thought ignore the religion. If the balance of normative tendencies and freedom of thought occurs, the arising civilization is creative cosmopolitanism because in it, the citizens take the initiative to look for the furthest insights from the obligation to hold on the truth (Wahid, 2011: 8-10).

The character of Islam that is open, tolerant, moderate, and respects the diversity of humanity, is the main characteristic of Muslims in formulating a great civilization. The future architects of Islam were born who created a wide variety of disciplines: there were physicists, astronomers, doctors, philosophers, and so on. Interestingly, beside mastering a wide range of scientific knowledge, Muslim intelligences also became religious figures who memorized the Qur'an and al-Hadith, tafsir (Quranic interpretation) expert, fiqh (Islamic jurisprudence) expert, and even tasawuf (sufism) experts. We may look at al-Ghazali, al-Kindi, Ibn Sina, Ibn Rusd, and so on (Usman, 2008: 190).

With the idea of Islamic universalism and Islamic cosmopolitanism as described above, we can understand that Gus Dur rejected the legalisticformalistic, scriptural or worldview alternative approaches which was completely apologetic. According to Gus Dur, such an approach cannot be expected much to solve the problem. In solving the problem of poverty for example, such an approach would only lead to a mere missionary effort, in the sense of how to strengthen faith and not vice versa like how to perceive faith that can arouse so that the problem of poverty can be solved equitably (Usman, 2008:192).

\section{Pribumisasi Islam}

One of the manifestations of Islamic cosmopolitanism initiated by Gus Dur in the context of Nusantara is Islam Pribumi. It was born from the attitude of Islamic openness in dialogue and self-manifestation into the local culture of 
Nusantara because logically, Islam will never come alone since its first era until now, there were religions and traditions that have been existed and preceded both in Mecca and Madinah, or other places all over the world, including in Indonesia (Mahmudah, 2018: 209). In Pribumisasi Islam, it is described how Islam as a normative principle from God is accommodated into a culture that comes from humans without losing their respective identities. The main purpose of the Pribumisasi Islam was that in order to preserve both Islam and the sharia in society wherever and whenever Islam will take place as a religion (Mahmudah, 2018: 209). Pribumisasi is not an effort to avoid the emergence of resistance from local culture forces, but an attempt to reconcile Islam with local culture forces so that the culture is not lost. Therefore, the core of Pribumisasi Islam is the need not to avoid polarization between religion and culture, because such polarization is inevitable (Wahid, 2015:34). Pribumisasi Islam has made religion and culture not defeat each other, but manifest in the pattern of religious comprehension that no longer takes its authentic form of religion, and seeks to unite a space that has been separating between religion and culture. Therefore, there is no longer a conflict between religion and culture (Fitriah, 2015: 9; Rahmat, 2003:43).

The idea of Pribumisasi Islam is based on the fact that according to Gus Dur, religion has culture has their own independence, but both were considered to have overlapping areas of relationship. Religion comes from revelation and has its own norms. Because it is normative, religion tends to be permanent, while culture comes from humans. In accordance with human life, culture fluctuates in change along with the development and tends to be changeable (Wahid, 2011: 33). As a starting point of the reconciliation effort between religion and culture is so that how the revelation is understood by considering contextual factors, including law awareness and a sense of justice.In this process, the renewal of Islam with culture must not occur, because according to Gus Dur, this means removing the nature of its authenticity. According to him, Islam must remain in its Islamic nature, the Qur'an must remain in Arabic, especially in prayer, because this is the norm (Wahid, 2015: 35). However, although Islam was born in Arabia, Islam is not identical with Arab culture, and there must be a fundamental distinction between religion (Islam) and Arab culture. In addition, Gus Dur said that in implementing the Pribumisasi Islam movement, we need the participation of all society elements in order to reaffirm the cultural roots of the society (Rosidi, 2017: 460). Pribumisasi Islam defined by Gus Dur was also not "Javanization" or "syncretization ", because Pribumisasi Islam only considered local needs in formulating religious laws, 
without adding the law itself, nor is it leaving the norms for the sake of culture, but so that the norms accommodate the needs of the culture by utilizing the opportunities provided by the understanding variation of Nas (Wahid, 2015:35).

Gus Dur believed and showed the world that traditional Islam was never static, and dynamic was the best expression of adaptive and flexible traditional Islam. Both between Islam and culture (tradition) take place and learn from each other (Mufidah, 2015: 96-97). One example of Pribumisasi Islam which had caused controversy among Muslims in Indonesia, even among the traditional Ulama' themselves, was when replacing Arabic greetings, "alSalamu alaikum" with "good morning". In this example, Gus Dur distinguished between saying greetings in Salat, which according to him was a normative rule, with greetings in culture and communication. In prayer, greetings still use Arabic, but in culture, this greeting can be replaced by language others according to the traditions of the people (Wijaya, 2012: 171).

The characters inherent in Islam Pribumi, namely; 1). Contextual, which means Islam is understood as a teaching related to the context of the era and place. The changes in time and regional differences are keys to the interpretation and ijtihad works. Thus, Islam will be able to continue renewing itself and be dynamic in responding to time changing. In addition, Islam dialogue flexibly with the conditions of people who differ from one side of the world to another. By the ability to adapt critically, Islam is actually can truly sholih li kulli zaman wa makan. 2). Tolerant, which means this Islamic context in turn makes us realize that the interpretation and understanding of diverse Islam is not a distortion when the work of ijtihad is carried out responsibly. Thus, this attitude will express a tolerant attitude towards various interpretations of Islam. Furthermore, awareness of reality, a pluralistic Indonesian context also requires sincere recognition of the equality of religions with all the consequences. This spirit of diversity is the pillar of the nativity of Indonesia; 3). Respect the tradition. When realizing that Islam (even at the time of the Prophet) was built on good old traditions, this is proof that Islam is not always contrast to local traditions. Tradition is not competed, but instead becomes a tool for vitality of Islamic values, because Islamic values need a framework that is familiar with the life of its believers; 4). Progressive, that is by changing religious practices. (Islam) is assumed that Islam accepts the progressive aspects of the teaching and the reality that it faces. The evolution of time is not inferred as a threat to the basic teachings of (Islam), but is seen as a trigger to do creative response intensively. By this characteristic, Islam can openly engage in dialogue with other people's thought traditions, including the 
West; 5). Unlocking Islam to become a teaching that can answer the real problems of humanity universally without seeing differences in religion and ethnicity. Islam is for human, for their own benefit. Therefore, Islam must be close to their daily problems. Islam not only talks about unseen world and worship, but is also familiar with the effort against oppression, poverty, backwardness, social anarchy, and so on. Islam belongs to small groups as well as large groups. Islam belongs to the poor and also the prosperous ones. Islam belongs to the oppressed people, not to the tyrants. By the spirit of liberation, Islam has not lost its capacity to assume the role of Rahmatal lil 'alamin (Rahmat, 2003: xxi-xxii).

\section{Conclusion}

Pribumisasi Islam is an effort to accommodate normative teachings from God into a culture that comes from humans without losing their respective identities. The idea of Islam Pribumi is an answer to authentic Islam which carries the project of Arabism or purification of Islam in every Islamic community throughout the world. However, according to Gus Dur, Arabism or the process of self-identifying with Middle Eastern culture is the uprooting from our own cultural roots. More than that, according to him, Arabism is not yet compatible with the needs of the people in Nusantara. Islam Pribumi is intended to provide opportunities for the diversity of interpretations in the practice of religious life (Islam). Thus, Islam is no longer seen as a single, but more pluralistic comprehension. Pribumisasi is not an effort to avoid the emergence of resistance from the strength of local cultures, but rather to keep the culture not lost. The inherent characters of Pribumisasi Islam are contextual, tolerant, respectful of tradition, progressive and liberating. This is the model or look of Islam Nusantara offered by Gus Dur as a solution in having peaceful and polite Islamic living in order to overcome the religious problem that is running into a conflict in several parts of the Islamic nations, especially in the Middle East today. 


\section{Reference}

Anwar, M. S. (2011). Islamku, Islam Anda, Islam Kita: Membingkai Potret Pemikiran Politik KH Abdurrahman Wahid, dalam Islamku, Islam Anda, Islam Kita: Agama Masyarakat Negara Demokrasi. In Democracy Project. Jakarta.

Azra, A. (2004). Shari'at Islam dalam Bingkai Nation State. In Paramadina. Jakarta.

Barton, G. (2002). Gus Dur The Authorized Biography of Abdurrahman Wahid. In Equinox Publishing Asia. Jakarta.

Baso, A. (2006). NU Studies: Pergolakan Pemikiran aatara Fundamentalisme Islam dan Fundamentalisme Neo-Liberal. In Erlangga (hal. 284). Jakarta.

Fitriah, A. (2015). Pemikiran Abdurrahman Wahid tentang Pribumisasi Islam. Teosofi: Jurnal Tasawuf dan Pemikiran Islam, 3(1), 39. https://doi.org/10.15642/teosofi.2013.3.1.39-59

Mahmudah, S. (2018). Islam and Local Traditions: The Study of the Thinkings of Abdurrahman Wahid (1940-2009) and Khalil Abdul Karim (1930-2002) an Indonesian and an Egyptian Perspective. Sunan Kalijaga: International Journal of Islamic Civilization, 1(2), 191. https://doi.org/10.14421/skijic.v1i2.1365

Mufidah, L. L. N. (2015). Pemikiran Gus Dur tentang Pendidikan Karakter dan Kearifan Lokal. Jurnal Al-Tahrir, 15(1), 91-110.

Rahmat. (2003). Islam Pribum, Islam Indonesia. In Erlangga.

Rosidi, R. (2017). Inklusivitas Pemikiran Keagamaan Abdurrahman Wahid. KALAM, 10(2), 445. https://doi.org/10.24042/klm.v10i2.9

Suprapto, B. (2009). Ensiklopedi Ulama Nusantara (Riwayat Hidup, Karya dan Sejarah Perjuangan 157 Ulama Nusantara). Gelegar Media Indonesia, 110.

Usman. (2008). Pemikiran Kosmopolit Gus Dur Dalam Bingkai Penelitian. Jurnal Masyarakat \& Budaya, 10(1).

Van Leur, J. (1955). Indonesia Trade and Society. In van Hoeve. Den Haag.

Wahid, A. (1988). Universalisme Islam dan Kosmopolitanisme Peradaban Islam. In Kontekstualisasi Doktrin Islam Dalam Sejarah: Yayasan Paramadina.

Wahid, A. (2007). Islam Kosmopolitan: Nilai-nilai Indonesia dan Transformasi Kebudayaan. In the Wahid Institute. Jakarta.

Wahid, A. (2011). Islamku, Islam Anda, Islam Kita: Agama Masyarakat Negara Demokrasi. In Democracy Project. Jakarta.

Wahid, A. (2015). Pribumisasi Islam. In A. Sahal \& M. Aziz (Ed.), Islam Nusantara dari Ushul Fiqh Hingga Paham Kebangsaan, Mizan. Bandung.

Wijaya, A. (2012). Menusantarakan Islam: Menelusuri Jejak Pergumulan Islam Yang Tak Kunjung Usai di Nusantara. In Nadi Pustaka. Yogyakarta.

Zada, K. (2003). Islam Pribumi: Mencari Wajah Islam Indonesia. Jurnal Tashwirul Afkar, (14). 